\title{
Cross-linguistic interaction and evolution of language: objective and subjective factors
}

\author{
Irina Mazirka ${ }^{1, *}$, Irina Donskova ${ }^{1}$, Sergey Smyslov ${ }^{1}$, Larisa Velikoredchanina ${ }^{1}$ \\ ${ }^{1}$ Moscow Region State University, Radio str., 10A, 105005, Moscow, Russia
}

\begin{abstract}
The present paper is aimed at investigating the role in the language development of a factor of its interaction with other languages, which is mostly pronounced within the process of translating different types of texts. Besides the linguacultural value, exploration of this phenomenon has general theoretical significance, since it is closely related, first, to the issue of correlation of internal and external factors that determine evolution of a language as a social phenomenon, and, second, to the issue of communicational potential peculiar to interacting idioms. The key research methods were the analysis of factual information obtained when having scrutinized the main tendencies observed in the process of resolving this issue during translation of foreign writings into Russian within different periods; defining the most illustrative translation methods used when having performed that process; highlighting different viewpoints of Russian and foreign scientists on the problem under consideration. The results of the research show, on the one hand, that the general idea of equality of communicational potential of different languages in different historical contexts requires certain amendments to be made, and on the other hand - that these amendments are determined not so much by linguistic, but more by extralinguistic factors that mainly stem from socioeconomic reasons. This, of course, does not preclude the subjective moments partly determined by translators' competence.
\end{abstract}

\section{Introduction}

In the first years of the Soviet regime (from October 1917) and later, domestic linguistics, which was a young Soviet science at that time, and particularly its "official" image and presentation, were based on ideas of the classics of Marxism. One of their statements is worth to be mentioned: "Although the most developed languages have laws and terms that are similar to those of the least developed ones, it is the difference from all universal and general things that creates their distinction" [10].

Unfortunately, the author of these words did not provide any specific analysis of these differences, which could be explained by the fact that he did not have such a purpose. Moreover, a socialist ideologist could hardly be considered a linguist. Since the entire USSR's scientific community was obliged to adhere to the principles of Marxism, scientists occasionally produced various liberal and often opposite to each other interpretations of

\footnotetext{
* Corresponding author: taniasemina@gmail.com
} 
words belonging to the classics of Marxism in relation to a number of scientific studies and tasks they were solving.

In this regard, the dispute between two prominent representatives of the Soviet linguistics of the middle of the last century - R. A. Budagov and L. S. Barkhudarov - is of particular interest. While Budarov proceeded from the fact that not all languages provide equal possibilities to convey certain ideas clearly and simply: "Not all languages are equally capable of conveying everything clearly and simply" [3], Barkhudarov stood for the opposite viewpoint, insisting that any language potentially possesses such capability: "We need to dispel doubts about the possibility of a complete and adequate communication of meanings expressed in one language by means of another language" [1].

Trying to find the roots of such kind of opinion (or doubt), shared by R. A. Budagov, one should point out the wrong judgment, or more likely the prejudice, which is very popular in linguistics, that all languages can be divided as follows: into "developed" and "undeveloped", "civilized" and "primitive", "important" and "all the rest", etc. In connection with the opinion accepted in linguistics (to this day as well) and which has become very popular among average people, the very concept of translatability, as well as all proofs of such a problem's existence take place only in the system of "developed" languages (if accepting the above-mentioned idea of language division), it appears that within the framework of "undeveloped" and "primitive" languages, the adequate translation of a text into another language may not be accomplished. Due to their so-called "primitiveness", such languages are not able to express the whole range and volume of meanings that can be communicated via "highly developed", "advanced" languages.

The purpose of this study is to identify and scrutinize the main aspects associated with the factor of cross-lingual interaction as a means of language development. One of the most important types of such interaction is translation, which is considered in the present paper as one of the most significant phenomena in sociolinguistic terms that determine this process.

\section{Methods}

The paper uses methods of analysis of the most illustrative data related to various historical periods, with the further identification of the most typical methods of their crosslinguistic conveying used by representatives of those periods, and with a subsequent comparison of the opinions on this issue shared by Russian and foreign authors.

\section{Results}

An analysis of the material studied shows that investigation into theoretical and practical aspects of interaction between a source and a target language within different periods proves the need to make certain amendments in the statement about the equality of their communicative potential, not so much in linguistic as in extralinguistic terms, which require taking into account socioeconomic background. At the same time, subjective aspects have to be taken into account, which relate to a person performing a translation with their linguistic and speech competencies.

\section{Discussion}

The ideas of R. A. Budagov about the inequality of languages are resolutely and, in our opinion, reasonably rejected by the majority of scientists, which we attribute ourselves to, having enough justification in this regard. The invalidity of Budagov's idea could have 
been substantiated (if taking into account political motives) even when there was the triumph of Marxism-Leninism ideology, which proclaimed "equality" of languages. This political platform, and especially its proclaimers clarified the situation and became the opponents of those who preferred to consider fair and reasoned distinguishing languages into "privileged" and "all the rest", which, in turn, was treated as the sociological racism that "replaced biological racism" [1]. If we ignore those aspects of the above-mentioned discussion that has been lasing for a long time, which was associated with ideological aspects determined by the era, it will be notable that its participants were not alone in their views. In addition, beliefs of some scientists come to mind about close connection of language evolution with its ability to properly convert everything said in one language into another one. This idea has long been widely discussed in the scientific community from different perspectives.

One of these perspectives consists in the supposal that development of a language is closely related to the history and methods of translation. Moreover, some researchers understand the very process of translating from a source language into a target language as a means of developing the target language (the one into which the text is translated). Here one may recall some statements of thinkers of the past, in particular, of one of the prominent representatives of French humanism, Etienne Dole, who believed that translation from a more developed source language would improve a target language: "translating from a more developed language to a less developed one, the translator must constantly strive to develop the latter" [2].

Another opinion on the influence of a translation process on language development lies in the desire, or even ability of specialists, who perform language transformation, to reproduce a foreign-language text of any complexity and dedicated to any area in any language (even the most "primitive") with the most accuracy, as far as accuracy of structures being interpreted is directly related to the development level of a target language. In this regard, there is given the idea of G.V. Leibniz (in its general sense) that any interpretation of a text into a foreign language is a "touchstone" that allows measuring the richness or penury of a translation language. One more of his thoughts comes to mind that "the richest and most convenient" is the language that can tail after an original text better than others $[17,18]$. Such kind of judgments and theories (regarding "richness" and "penury" of languages) were supported and promoted by a quite significant number of world-known scientists. However, in order to avoid expanding this research too much, we give only two, but the most important aspects that belong to the problem area of our interest.

The first aspect of its solution lies in clarifying the status of the "translatability theory" itself: whether this problem can be considered resolvable exclusively within the framework of certain languages, moreover, only when this framework is defined or restricted. Then it is necessary to sound out the importance of all this "work on clarification", that is, to answer the question, if it is necessary to compare factors affecting the development of a source language and a target language, to know their lexical state relatively to each other at the moment of translation in order to determine the level of adequacy of text transformation.

Since the main topic of this study is the issue of evolution and development level of languages, not the question of translation adequacy, we would like to express a number of thoughts, and in this regard provide a well-known opinion of Ferdinand de Saussure on the differentiation of synchrony and diachrony; thereat we consider it necessary to clarify which particular aspect (static or dynamic) is meant. The static aspect implies the process of translating that is performed within a specifically designated period, whereas the dynamic aspect deals with cases when the source and target languages are nor chronologically correlative. We believe that this fact clearly illustrates the certain relativity of the concept 
of "developed language" in a certain period, since at each given moment it has a potential reserve of idioms besides actual ones. At the same time, the history of certain languages may indicate that the potential of expression does not always allow overcoming difficulties that arise during crosslinguistic communication on a particular synchronous "layer" of the language existence and functioning. Moreover, this applies not only to the so-called exotic languages, which were actually meant by Budagov and scientists who shared his opinion, but also to such idioms, which are considered undoubtedly highly developed. Back in the 50 s of the last century, professional literature including foreign works admitted that the Russian language was one of the most significant languages in the world, socially and politically second only to English. To confirm this, we give the words of the famous American scientist about the Russian language as one of the "leading languages of the world", since "it is second only to the English language in its social and political significance" [5].

However, the events of the last decades of the $20^{\text {th }}$ century that happened in the USSR, and more specifically, related to its collapse, and the situation that developed due to the difficult and rapid transition to a new "spontaneous market economy" that was mostly incomprehensible for Soviet citizens escalated the need for fast translation into Russian of a large number of foreign texts. This, in turn, led to the appearance of a significant number of works dedicated to conveying terms from foreign literature that were new for Russia that was changing and moving towards market relationship. Such translations were carried out very intensively ("in a limited time" and under excessive consumer pressure). It is hardly surprising that such translations were often far from high quality, so they remarkably exposed "terminological hunger" even in such a developed language as Russian.

Both writings and speeches became full of such loanwords as лизинг (leasing), франчайзинг (franchising), дистрибьютор (distributor), джоббер (jobber), фрилансер (freelancer), etc. These words borrowed from foreign languages were understood partially or completely misunderstood by average Russian-speaking citizens of then-Russia. Even those members of the society who had good knowledge of a foreign language that was an etymological source of these words and phrases (mainly English) sometimes could hardly find their equivalents in their native language.

Due to the negative factor of such a rapid and excessive "foreign invasion" into the vocabulary of the Russian language, Russian society started raising questions about the contamination of the language with alien elements, which certainly led to its decay, according to beliefs of those who criticized this process. However, it was mentioned several times that there are such exceptional situations when "loaning of words becomes the only way to name phenomena that came from abroad", which results in the fact that even the Russian language, which has enormous potential, "almost loses its internal translation mechanisms" [7]. It was noted that "now we are not creating social, professional and cultural relations, but rather loan them together with corresponding words, which means that we live under conditions of broadcasting foreign culture" [7]. If talking about the mission of messengers - translators of texts belonging to a "foreign culture" into a native language - then, perhaps, at that time economists and linguists reckoned (and continue reckoning) on them and on adequate results of their work. Thus, no matter how we relate to the problem of redundancy of loanwords and contamination of a language with them: sometimes there is simply no other option, which would be more aesthetic and productive at the same time, to convey information. What exactly should be translated and what might be omitted (regarding "specimens of culture") is most often determined not by a "messenger" of this process and is not dictated only by their desire, but is aimed more at resolution of existing, emerging and constantly changing situations in the market, in connection with its constantly increasing needs. The tasks of a translator include finding the way or determining the method, according to which they will most accurately and 
adequately perform this process under a hard situation of the market economy, which in addition is spontaneously developing. Such scenario was typical for the period of development of Russian society, which is being described, and it obviously affected the language of this society.

Of course, in some cases (perhaps in the majority of them), such a practice (should an item be translated or not? If yes, then how it should be done and what to expect from a particular act of translation? Why one example of translation is perceived positively, while another is not?) is usually associated with subjective assessment of the work proposed by a translator and with their personal qualities and professional skills. It should be kept in mind that the very concept of the level of translation skills in any period of history represents not so much an absolute value as a relative one. This fact often leads to statements that firstly seem a little inconsistent: on the one hand, attention is drawn on the skill of cross-lingual transmission acquired during a certain period, while, on the other hand, a rather low quality level of mass products is noted. For instance, A. V. Fedorov in his well-known textbook pays much attention to the contribution made by representatives of the Silver Age of Russian literature to literary translation. Their achievements in this field are highly appreciated. However, the work of A. V. Fedorov provides a rather pessimistic description of the situation in this field at the turn of the $19^{\text {th }}-20^{\text {th }}$ centuries: "The quality of translations was falling: they were increasingly acquiring mechanical nature. Some people considered translation as a quite easy work, not requiring any responsibility or special data, except for the general knowledge of a foreign language. Therefore, translations were often entrusted to random people who knew a source language or a target language (or even both of them) insufficiently" [16]. Nevertheless, we consider it absolutely wrong and unprofessional to refer only to cases of translators' dilettantism, at least in this regard, since we consider such an opinion to be scientifically unfounded, and therefore biased. If accepting the idea that language is a public phenomenon, then it is reasonable to assume that in the situation being described, the Russian language turned out to be as unprepared for the "invasion" of foreign words (including the redundancy of foreign terms), as the Soviet and then Russian society, which both did not understand newly developed phenomena and processes that, of course, were denominated by words, which were new for the citizens.

During the period of the Soviet Union, higher education programs in any Soviet university (regardless of its field of study) were developed according to uniform standards in the study of social disciplines (including the political economy of capitalism). Moreover, such courses were compulsory, while the interpretation of everything relating to capitalism was always negative, which was reflected in the use of relevant vocabulary and phraseology of the Russian language. There was a situation when certain speech clichés and lexical units that "ensured criticism of the capitalist methods of production" and were needed by students only to pass the exam, at the time of Perestroika turned out to be incomprehensible for most people and, most importantly, insufficient to designate and reflect a huge number of new phenomena happening in the country. These phenomena previously had been vague and "alien" for Russian people, but they instantly became their new reality to perceive.

Such a complex linguacultural situation led to the acute need and urgency of resolving it, and, as might be assumed, it was not always solved correctly and timely. Of course, no one thought or spoke of any "underdevelopment" or "primitiveness" of the Russian language, because translatability (or everything related to it) in this particular case is not so much linguistic, as extralinguistic by its nature and has a direct connection with those social processes that involve a particular language (functioning in these processes). One cannot deny that the linguistic aspect of the problem, and particularly, the use by translators of various methods of cross-lingual conveying of vocabulary, is certainly associated with the 
tools of a target language. This process should be performed under the obligatory consideration of the traditions that are entrenched in a target language, and in compliance not only with its linguistic and speech rules, but also in accordance with the speech culture approved among its speakers, with the existing speech patterns, clichés, etc. However, it should be noted that all the above-said is associated not so much with lexical and phraseological richness of a target language, that is, with its "development level", but with a translation technique and professional competence of a mediator.

In this regard, it seems reasonable and important for us to recall the period of the development of the Russian language during the reign of Peter the Great and the period after Peter, or rather to point out the processes that occurred in the Russian language during the so-called time of its intensive "Europeanization", which started more than 300 years ago and can be partly comparable to the modern process of its "globalization".

Such a revolution in a language was provoked by the acute need of the Russian educated population to master, designate or adapt new concepts that were mostly unfamiliar to people before the major reforms of Peter the Great. It is interesting that more than 300 years ago the question was not about creating any specific terminological systems, which, for example, was faced by Russian-speaking citizens during perestroika and the postperestroika period, but about the creation of the whole new scientific and technical functional style. Words of the outstanding historian S. M. Solovyov characterize that complicated linguistic situation of "terrible difficulty of conveying scientific concepts in the language of people, who even had no science until then" [15]. Russian authors tried to manage this problem by various methods. The most natural often seemed to be a combination of loaning a foreign lexical unit with an explanation of its meaning. In the first half of the $18^{\text {th }}$ century, A. D. Kantemir chose a similar path for a number of his translations. He justified the use of loanwords by the absence of tantamount Russian equivalents, which he was unwillingly forced to use, having no equivalents of his own [14]. However, this method did not always lead to success, as evidenced by an anecdote, which was clearly written by foreigners, yet having some real-life basis, about a very talented translator who could not cope with the tsar's order to translate a writing about gardening from French (Le Jardinage de Quintiny) due to the abundance of special technical terms that did not have any equivalents in Russian, which allegedly led him to commit suicide in despair about this [12].

The great scientist M. V. Lomonosov had to face similar difficulties, who noted (as A. D. Kantemir had done several decades before him) the need to "look for words to name some physical instruments and natural things that at first seem somewhat strange" [14]. It is remarkable that this confession did not prevent Lomonosov from defending the idea about the extraordinary richness and high development level of the contemporary Russian language, including the field of "linguistic support" of scientific activity, as evidenced by his statement that is often quoted: "The subtlest philosophical imaginations and reasoning, the diverse natural properties and changes that are in this visible structure of the world and in human appeals, have decent and expressive things in our speech. And if we cannot accurately depict anything, then we shall attribute this not to our language, but to our insufficient art in it" [8].

Despite the apparent paradox of this position (on the one hand, the Russian language, according to Lomonosov, has all the necessary tools for the implementation of scientific creativity, and on the other hand, the scientist has to introduce new units, including those that "seem somewhat strange"), it seems that the contradiction is purely external, since the Russian language was enriched by various ways, including loaning necessary elements (see below for more details).

Of course, we consider it quite possible that in the middle of the $18^{\text {th }}$ century such an assessment of the Russian language (even by such a person as M. V. Lomonosov) was 
partly premature and could be interpreted nor from the perspective of objective linguistic principles, but rather be explained by the position of the author of these statements and his subjective patriotic beliefs. So here (as a confirmation of this thought), the words said (though much later) by another great Russian person, poet Alexander Pushkin, are recalled: "scholarship, politics and philosophy have not yet been explained in Russian: we don't have a metaphysical language at all" [13]. Nevertheless, M.V. Lomonosov still turned out to be right, since by the middle of the $19^{\text {th }}$ century the whole translation of foreign scientific literature into Russian (and the appearance of a large number of new works in domestic science) from the perspective of their translation (as well as the use of terminology in Russian) was quite consistent with the relevant "European" level.

Moreover, another part of what M. V. Lomonosov said - about his own art in the language - was also implemented. The authors, at least most of them, who were involved in the work on terminology quite assumedly expected to consolidate the results of their work within the framework of the language. Such questions have been discussed plenty of times. We would give several names of scientists who were interested in fixing new terms in the Russian language. This is, first of all, A. D. Kantemir, who, having dreamed of it, said: "I have so much hope that those new words and sayings that I introduced do not oppose the affinity of the Russian language, and over time these novelties may be appropriated to the people, so that they will not demand any explanations" [14].

We would compare these words to the opinion of V. K. Trediakovsky, who, while having searched necessary lexical units, addressed to the heritage of the Church Slavonic language [4]. The role of the Church Slavonic heritage in the development of the Russian language was also described by M. V. Lomonosov, who, explaining his thought, recalled the infusion of Greek elements into the Slavic language, which greatly contributed to its enrichment: "This wealth was acquired most of all through Greek Christian law, while church books were translated from Greek to Slavonic for the praise of God <... Although many segments of these translations are not quite intelligible; however, our benefit is great. Although it cannot be rebuked that at first that books translated from Greek into Slavic could not avoid acquiring Greek properties, that are alien to the Slavic language, however, after a long time they ceased to be disgusting for the Slavic hearing and became customary to it. So things that seemed unintelligible to our forefathers, now have become pleasant and useful for us" [14].

At the same time, the following so-called equivalents of V. K. Trediakovsky should be mentioned: “безместие" for absurdité, "недействие" for inertie, “предверженная вещь" for object, etc. Today they seem ridiculous and strange for Russian speakers, while Lomonosov's “созвездие” (constellation), “кислород” (oxygen), “водород” (hydrogen) and other words are perceived linguistically original Russian words, that is, "they like have been initially born in the Russian language" [9].

\section{Conclusion}

G. O. Vinokur, speaking of the necessity and complexity of choosing ways to translate foreign-language terms, noted that by the $18^{\text {th }}$ century such terms had already existed, and moreover, were actively used by representatives of Russian cultural life. People who translated those terms often demonstrated the similarity of methods used for translating special vocabulary into Russian, they followed the same way as their predecessors when having performed activities related to formation and development of Russian terminology. Further history has shown that this approach was reasonable and once again confirmed Wilhelm von Humboldt's statement that, according to the facts obtained during studying the history of translation of various languages, "even though with different accuracy, every thought can be expressed in any language" [6]. 
It certainly should be kept in mind that progress in Russian science and technology significantly contributed to the successful formation of Russian terminology. It seems convincing that, since translation is not only the cross-lingual mediation, but also the cultural interaction, in order to use Wilhelm von Humboldt's statement given above, it is necessary for the bespoken "accuracy" to satisfy the requirement of adequacy, as well as correspond to cultures of both source and target languages that belong to peoples that are comparable in terms of this parameter, i.e. standing approximately at the same level of development [11].

\section{References}

1. L.S. Barkhudarov, Yazyk i perevod (Voprosy obshchey i chastnoy teorii perevoda) (M., Izd. stereotip. URSS, 2019)

2. R.A. Budagov, Literaturnyye yazyki i yazykovyye stili (M., Vysshaya shkola, 1967)

3. R.A. Budagov, Chto takoye razvitiye i sovershenstvovaniye yazyka? (M., Dobrosvet2000, 2004)

4. G.O. Vinokur, Russkiy literaturnyy yazyk $v$ pervoy polovine XVIII veka, http://philology.ru/linguistics2/vinokur-59b.htm

5. H. Gleason, Vvedeniye v deskriptivnuyu lingvistiku (M., URSS,2008)

6. W. fon Humboldt, Izbrannyye trudy po yazykoznaniyu (M., Progress, 2000) https://www.rulit.me/books/izbrannye-trudy-po-yazykoznaniyu-read-213842-1.html

7. M. Krongauz, Russkiy yazyk na grani nervnogo sryva (M., Znak: YAzyki slavyanskikh kul'tur, 2008)

8. M.V. Lomonosov, Izbrannaya proza (M., Sov. Rossiya, 1986)

9. I.O. Mazirka, G.T. Khukhuni, Perevodimost' kak kriteriy razvitiya yazyka (2020) https://cyberleninka.ru/article/n/perevodimost-kak-kriteriy-razvitiya-yazyka/viewer

10. K. Marks, $K$ kritike politicheskoy ekonomii https://www.marxists.org/russkij/marx/1859/criticism_pol_econ/index.htm

(2020)

11. L.L. Nelyubin, Tolkovyy perevodovedcheskiy slovar'. 8-ye izd (M., Flinta, 2016)

12. P.P. Pekarskiy, Nauka i literatura v Rossii pri Petre Velikom. Tom 1. (Vvedeniye v istoriyu prosveshcheniya $v$ Rossii XVIII stoletiya) (SPb., Tovarishchestvo «Obshchestvennaya pol'za», 1862)

13. A.S. Pushkin, Poln. sobr. soch.: V 10-ti tt. AN SSSR. In-t rus. lit. (Pushkinskiy Dom) 4ye izd (L., «Nauka» Leningradskoye otd, 1978) https://coollib.com/b/402531

14. Y.D. Levina, A.F. Fedorova, Russkiye pisateli o perevode (L., Sovetskiy pisatel', 1960)

15. S.M. Solovyev, Izbrannyye trudy. Zapiski (M.: Izdatel'stvo MGU, 1983)

16. A.V. Fedorov, Osnovy obshchey teorii perevoda (M, Izdatel'skiy dom «FILOLOGIYA TRI», SPB: Filologicheskiy fakul'tet SPbGU, 2002)

17. R. Klopfer, Die Theorie der literarischen Übersetzung (Munchen, Fink, 1967)

18. W. Sdun, Probleme und Theorien des Übersetzens (München, Hueber, 1967) 